\title{
An Examination of REIT Dividend Payout Policy
}

\author{
Walter I. Boudry, Leonard N. Stern School of Business
}

This paper proposes a new methodology for decomposing real estate investment trust (REIT) dividends into discretionary and nondiscretionary components. By examining the tax characteristics of dividends, I am able to accurately measure the discretionary component of a REIT's dividend. This methodology provides new insights into our understanding of REIT dividend payout policy. Unlike previous studies that find limited explanations for discretionary dividend payouts, I find a systematic explanation. Discretionary dividends tend to be large on average making up between $18 \%$ and $35 \%$ of a REIT's total dividend and display considerable variation through time and across firms. The main determinant of these discretionary dividends appears to be dividend smoothing. There is an inverse relationship between discretionary and nondiscretionary dividends. Even if a REIT has excess cash flow it could distribute in discretionary dividends, it will tend not to do so if it has a high dividend payout due to its nondiscretionary dividends. In this sense, REITs appear to use discretionary dividends to smooth their payout ratios.

The choice of a firm to pay or not pay dividends is a central theme in corporate finance. A vast literature has developed devoted solely to explain why firms choose to pay dividends. The central assumption in this literature is that the firm has a choice in paying dividends. For regular corporations this assumption is quite reasonable. However, when one tries to explore the dividend policy of a real estate investment trust (REIT), the legislative environment in which the REIT operates comes to the fore.

At its simplest, legislative considerations force a REIT to distribute at least part of its cash flows as dividends. In this sense the distribution behavior of a REIT needs to be broken into nondiscretionary and discretionary distributions, because it is the payment of the discretionary distributions that is a choice made by REIT management. What makes this distinction difficult is that the distribution requirements that a REIT faces are largely based on taxable income. As is well known in the tax literature, calculating taxable income based on mandated disclosures from Statement of Financial Accounting Standards No. (SFAS) 109 Accounting for Income Taxes (Financial Accounting Standards Board 1992) is highly problematic (see Hanlon 2003). 
In this article I propose a simple methodology for calculating a REIT's discretionary dividends. The reason for proposing a new methodology is quite simple: the methodologies proposed in the prior literature are flawed from two perspectives. First, prior methods use generally accepted accounting principles (GAAP) financials to estimate taxable income. It is well known in the tax literature that this exercise is likely to lead to large errors (see Hanlon 2003). Second, having calculated taxable income, they apply an incorrect rule to determine what level of dividends is nondiscretionary and what level is discretionary. That is, even if they had by chance calculated the correct taxable income, they would still have calculated the wrong level of discretionary dividends because they fail to incorporate the actual distribution requirements stated in the tax code.

The approach I adopt in this article to calculate discretionary dividends alleviates these problems in two ways. First, I do not use GAAP financials to calculate taxable income. Instead I use the required tax disclosures from Form 1099-DIV to estimate taxable income. By starting with tax disclosures I am not prone to the same GAAP-to-tax differences that plague prior methods. Second, the payout rule I apply to my estimate of taxable income is determined by the payout requirements mandated in the Internal Revenue Code (IRC). ${ }^{1}$ In fact, I will argue that there is more than one potential definition of discretionary and nondiscretionary dividend: one based on maintaining REIT status and one that eliminates the firm's federal income tax.

Having addressed the issue of identifying the discretionary dividends paid by a REIT, the paper examines two main topics. The first is to characterize the magnitude of the discretionary dividends. Although many papers have argued that REITs pay discretionary dividends (see, e.g., Wang, Erikson and Gau 1993) none have accurately described these distributions. Second, I examine whether the competing theories of dividend policy can explain the discretionary dividend policy observed in REITs. Because the total dividend paid by a REIT is composed of both discretionary and nondiscretionary components, accurately identifying the discretionary component gives this study greater power to test the competing theories than previous studies.

For a sample of 113 equity REITs between 1997 and 2007 I find discretionary dividends are on average a significant portion of a REIT's total dividend, making up between $18 \%$ and $35 \%$ of the total dividend paid. This is consistent with the assumption adopted in the prior literature that REITs, in general, pay discretionary dividends. However, further examination of the data reveals that there is more to this story. There is a great deal of cross-sectional and time-series variation in the payment of

\footnotetext{
${ }^{1}$ The formal citation for the IRC is Title 26 United States Code. As is customary, I use the less formal citation of IRC throughout.
} 
discretionary dividends. Using my most restrictive definition, on average only $61 \%$ of REITs are paying discretionary dividends in any given year. Some firms pay discretionary dividends every year, whereas others never pay discretionary dividends during the sample period. Furthermore, the magnitude of the discretionary dividend can vary greatly between years. In some years there is no discretionary dividend, whereas in others the whole distribution is a discretionary dividend. These results suggest that it can be misleading to merely assume that REITs always pay discretionary dividends as has been done in the prior literature.

I find that several factors explain the discretionary dividend payment of REITs. First, consistent with Lintner (1956), I find support for dividend smoothing. Although discretionary dividends are a positive function of excess cash flow, they are negatively related to the current nondiscretionary dividend yield. Controlling for excess cash flows, a REIT is less likely to pay discretionary dividends if its dividend yield from nondiscretionary distributions is already high. In this sense it appears that REITs use discretionary dividends to manage their overall dividend payout. They are more likely to pay discretionary dividends when nondiscretionary payouts are low and less likely to pay discretionary dividends when nondiscretionary payouts are high.

Second, capital markets do appear to play a role in discretionary dividend payments. Firms with better financial access, as proxied by Tobin's $Q$, tend to have higher discretionary dividend payments.

Finally, repurchases and discretionary dividends appear to be substitutes. Firms that repurchase stock tend to have lower discretionary dividends.

This article provides two major contributions to the literature. First, from a methodological standpoint, it provides a simple and accurate way to calculate discretionary and nondiscretionary dividends. Second, my results show that prior studies are quite misleading when it comes to REIT discretionary dividend payout policy. Hardin and Hill (2008) find little in the way of a systematic explanation of REIT dividend policy. In their various regressions, the only factor that is consistently significant is an inverse relationship between repurchases and discretionary dividends. Although I show this is true, it is far from the most economically and statistically significant explanation. Based on the results of the prior literature, one would conclude that REIT dividend payout policy appears far different from that of regular firms. I show that, once you correctly identify discretionary dividends, REITs appear to follow a dividend smoothing policy that is similar to regular corporations.

The rest of the article is organized as follows. The next section discusses the prior literature, which is then followed by a discussion of REIT distribution and taxation regulations. I then test the 
competing theories of dividend payout policy, and the final section of the article provides my conclusions.

\section{Literature Review}

\section{Dividend Literature}

There is an expansive literature examining the dividend payout policy of regular corporations (see Allen and Michaely 2003 for an extensive summary). The REIT literature follows similar themes. Traditionally, the dividend payout policy of a firm is generally argued to be either the outcome of agency costs or dividend signaling. Agency cost models argue that firms should pay higher dividends when they face high agency costs (see Easterbrook 1984, Jensen 1986). If managers are free to use excess company cash flows for their own benefit or to empire build this imposes costs on shareholders. Managers may be able to ameliorate some of these agency costs by paying out dividends. Dividend payments reduce free cash flow and can also force the firm to come to the capital markets to raise capital. The additional monitoring that arises from raising new capital should limit the manager's ability to invest in negative net present value projects.

Signaling models of dividend behavior argue that managers may use their dividend payments to signal private information about their expectation of future cash flows (see, e.g., Miller and Rock 1985, Bhattacharya 1979). These models are based on the assumption that dividends are costly and as such can be used by management as a credible signal of private information.

More recently the literature has considered other potential explanations of a firm's dividend payout policy. Baker and Wurgler (2004) argue that firms may cater their dividends to investors. When investors value dividends highly, firms should be more inclined to pay dividends. Baker and Wurgler (2004) and Li and Lie (2006) demonstrate that firms do appear to follow this catering behavior. Firms are more likely to increase dividends when dividends are more highly valued by the capital markets.

The early REIT dividend literature was quite limited because REITs were viewed as having a payout policy determined solely by legislation (see, e.g., Lee and Kau 1987). More recently, Gentry, Kemsley and Mayer (2003) also explicitly point out that REITs have little discretion over their dividend payout. Wang, Erikson and Gau (1993) were the first to point out that REIT dividend policy may not be completely determined by legislation. In their sample of firms, they observe that REITs tend to pay 
significantly more in dividends than their net income. ${ }^{2}$ This suggested that there is some discretionary component to a REIT's dividend, although they were unable to quantify the amount. Testing total dividends, they find some support for the agency cost model of dividends. REITs tend to pay higher dividends when agency costs are likely to be high. They also find that dividend changes convey information. Positive (negative) dividend changes are associated with positive (negative) announcement period returns.

Bradley, Capozza and Seguin (1998) extend the REIT dividend literature by simultaneously examining agency costs and signaling models. Their insight is that the models have different predictions with respect to cash flow volatility. Under the agency cost model, firms with high cash flow volatility are also likely to suffer from high asymmetric information and agency costs. If this is true, high expected cash flow volatility should be positively related to higher dividend payout to reduce agency costs. Under dividend signaling models, the firm finds it costly to decrease dividends and as such will try to avoid doing this. Firms that have highly volatile cash flows are the firms most likely to have to cut dividends. This suggests that high expected cash flow volatility should be associated with a lower dividend payout. In their testing they find some support for the signaling theory. Firms that are likely to have high cash flow volatility tend to pay lower dividends.

The paper most closely related to this study is Hardin and Hill (2008). Hardin and Hill (2008) propose bifurcating a REIT's dividend into required and excess components. ${ }^{3}$ In their study they proxy for required dividends by simply adding back Income Tax Paid to Net Income and then taking $90 \%$ of this "Taxable Income" as the required dividend. The difference between Total Dividends Paid and the required dividend is the discretionary dividend. Using their measure of discretionary dividends, they find some support for the notion that access to the capital markets is a key influence on dividend policy. However, their study suffers from a critical drawback in that it relies on reported financial data to calculate the required component of dividends. As noted by Wang, Erikson and Gau (1993), it is not possible to calculate a REIT's taxable income from required financial statement disclosures. As discussed later (and highlighted in the Appendix), the magnitude of the error this method causes can be quite large.

Two other papers in the literature examine the Form 1099-DIV taxable components of dividends. Downs, Guner and Patterson (2000) examine the relationship between returning capital and

\footnotetext{
${ }^{2}$ Although they note that Net Income and Taxable Income are not the same, they argue that it is unlikely that a REIT would pay out only nondiscretionary dividends and also have this amount be a multiple of GAAP Net Income. ${ }^{3}$ This is in the same spirit as my discretionary and nondiscretionary bifurcation, although the nature of the two components is quite different in the two studies.
} 
asymmetric information. They find that firms with higher distribution policies tend to have lower asymmetric information, but they find that the market treats distributions from nontaxable returns of capital and ordinary income the same. Recently, Li and Weber (2007) examine the ex-day pricing of REIT dividends using the taxable components of dividends. The main limitation of their study is that the market does not know the taxable makeup of the dividend at the time the quarterly dividend is paid. As such it is hard to infer exactly what any ex-day effect actually represents.

\section{Tax Literature}

The issue of estimating taxable income from mandatory disclosures under SFAS 109 has received some attention. The standard approach proposed in the tax literature is to gross up current income taxes at the top marginal rate. ${ }^{4}$ However, Hanlon (2003) argues that this approach is likely to be very inaccurate except for the simplest of corporate structures. She argues that differing tax and GAAP treatments of stock options expense, consolidation rules, the tax cushion and intraperiod tax allocations are likely to make any inference erroneous. In effect, the firm does not disclose enough information under SFAS 109 for an observer to reengineer the firm's tax accounts.

Lisowsky (2009) builds on the arguments of Hanlon (2003) and, using a sample of private Internal Revenue Service (IRS) tax returns, estimates that, for every dollar of income tax expense reported in the financial statements, approximately $\$ 0.70$ is reported on the firm's tax return. So on average there are significant differences between tax and GAAP numbers.

Taxable income disclosures have also received attention in the context of REITs. Since 2001, National Association of Real Estate Investment Trust (NAREIT) has proposed firms make a voluntary disclosure related to taxable income and provide a reconciliation of Net Income to Taxable Income for the firm (see Taube and Yungmann 2001). This disclosure is voluntary and an examination of firm annual reports shows that it has not been widely adopted and where it has, it has not been uniformly reported. This makes any analysis using this data problematic.

\section{REIT Distribution Requirements and Taxation}

The legislation related to REIT taxation can be found in IRC sections 856-860. Although a complete discussion of the legislation is outside the scope of this study, three pertinent topics warrant some discussion. The first of these is the issue of maintaining REIT status. REITs are required to make certain distributions in order to maintain their tax-preferred status. I will outline what these

\footnotetext{
${ }^{4}$ See, for example, Manzon and Plesko (2002), Omer, Malloy and Ziebart (1991) and Gupta and Newberry (1997).
} 
distributions are below and discuss how they are often misrepresented in the academic literature. Second, although it is commonly assumed that REITs are tax exempt, this is in fact untrue. REITs do in fact face taxation on their income and capital gains. I argue that the potential of paying income taxes and the firm's ability to avoid paying these taxes provides obvious incentives for REIT managers. That is, REIT managers may have a different nondiscretionary distribution benchmark than the one that simply ensures that the REIT maintains status. Finally, I examine the calculation of taxable income. Because taxable income is the cornerstone of REIT distribution requirements, some care needs to be taken in understanding how potential measures of taxable income can differ from the taxable income that the REIT reports to the IRS.

\section{Maintaining REIT Status}

IRC section 857 outlines the distribution requirements that a REIT must meet to maintain REIT status. In the REIT literature, this section is commonly summarized as "a REIT is required to distribute at least $90 \%$ of its taxable income in dividends in order to maintain REIT status." Although commonly quoted, this is in fact very misleading. A more accurate description is, to maintain REIT status a REIT is required to distribute dividends equal to at least: $90 \%$ of its REIT taxable income (excluding any dividends paid deduction and net capital gains), plus $90 \%$ of foreclosure income less the tax paid on that income, less certain excess noncash income.

For a typical equity REIT both foreclosure income ${ }^{5}$ and excess noncash income ${ }^{6}$ are likely to be small. The fact that the typically quoted $90 \%$ rule omits them is not an egregious error. However, notice that net capital gains do not have to be distributed in order for the REIT to maintain status. Any calculation of the nondiscretionary dividends that does not account for taxable capital gains, such as that proposed by Hardin and Hill (2008), is likely to be biased. Below I show these capital gains are on average large, suggesting that the bias inherent in the Hardin and Hill (2008) method due solely to an incorrect interpretation of the IRC is also likely to be large.

\footnotetext{
${ }^{5}$ Foreclosure income for an equity REIT is most likely to come in the form of rents from space that have tenant improvements that the REIT acquires when a tenant defaults on a lease. If the REIT were to subsequently sell the property then these tenant improvements may violate the prohibited transactions rules under IRC section 856 . By declaring this property foreclosure property the REIT pays tax on the income and will not violate the prohibited transaction rule. Notice that, if the REIT does not plan to sell the property, then no election of foreclosure status is necessary.

${ }^{6}$ The typical source of excess noncash income for the REIT is cancelation of debt income. Although this is treated as income for tax purposes, there is no cash flow associated with this income. This mismatch between cash and taxable income may lead to a REIT being unable to pay enough dividends to maintain status if this noncash income was included in the distribution requirement.
} 


\section{REIT Taxation}

Maintaining REIT status is not the only tax incentive a REIT faces when paying dividends. Although a REIT can retain $10 \%$ of its taxable income and all of its net capital gains and still maintain status, any amounts of these that are retained are taxed at corporate rates. From an investor perspective, paying these taxes is a transfer of wealth from investors to the government. The simple reason for this is that, if all of the REIT's taxable income and net capital gains are distributed to investors, then the REIT does not pay federal corporate income tax. In this case the taxable income and net capital gains will be taxed only once (in the hands of the investors), and this is more than likely to occur at lower tax rates. ${ }^{7}$

The taxation of retained taxable income and net capital gains suggests that there is a second potential definition of discretionary and nondiscretionary dividends. A REIT that simply distributes dividends to maintain status is likely to be destroying investor value by paying unnecessary corporate income taxes. In a rational market one would expect such value-destroying behavior to be punished by investors. As such it is logical to consider the minimum distribution requirement that a REIT would make to be $100 \%$ of its taxable income and net capital gains. This would ensure that the REIT does not pay federal corporate income taxes.

\section{Calculating Taxable Income}

The obvious starting point for estimating both measures of discretionary dividends is the calculation of taxable income. The problem with this is that taxable income is not a required disclosure under SFAS 109, which means that taxable income can only be approximated.

In the tax literature the approach commonly taken is to gross up income tax paid at the highest marginal tax rate. ${ }^{8}$ Although there are reasons to believe this is problematic for regular firms, it is likely to be extremely inaccurate for REITs because in general the taxes that a REIT reports in its financial statements relate to Taxable REIT Subsidiaries (TRS), not to federal corporate income tax.

Hardin and Hill (2008) propose taking net income and adding back income taxes paid and using this as an estimate of taxable income. This approach is likely to be very inaccurate for a number of reasons. First, as discussed earlier, income taxes paid for a REIT generally relate to TRS activity. Second, as discussed in Hanlon (2003), there are in general large differences between GAAP and tax accounting.

\footnotetext{
${ }^{7}$ As will be discussed later, taxable income is taxed at the investor's marginal rate, while it is taxed at marginal corporate rates if the REIT retains it. Net capital gains are taxed at either $15 \%$ or $25 \%$ in the hands of investors, whereas the REIT faces a 35\% marginal rate if they retain them.

${ }^{8}$ See, for example, Manzon and Plesko (2002), Omer, Malloy and Ziebart (1991) and Gupta and Newberry (1997).
} 
For a REIT, differences between GAAP and tax accounting for depreciation, capital gains and stock options are likely to be significant. From a pure accounting perspective, there is reason to be concerned about any method that attacks taxable income from GAAP financials. This is essentially why both academics and practitioners have suggested firms make more detailed disclosures regarding taxable income than those requires under SFAS 109.

The approach adopted in this article is quite different from that used in the prior literature. I use mandatory tax disclosures made by the REIT to infer the REIT's taxable income. Because REITs are a pass-through structure, REIT dividends do not generally qualify for favorable tax treatment. Each year a REIT reports to shareholders the taxable makeup of its dividends in Form 1099-DIV. The makeup of dividends takes essentially three forms: (1) ordinary income, (2) capital gains and (3) nontaxable returns of capital. ${ }^{9}$

The tax component of a REIT's dividend is determined by the characteristics of the income that the REIT paid as dividends. If the REIT paid dividends out of Earnings and Profits (E\&P) then the dividend has the form of ordinary income. If the REIT paid out the capital gains from the sale of properties, then this has the form of capital gains. ${ }^{10}$ Finally, if the REIT returns the tax basis of properties or pays out greater than $100 \%$ of its E\&P, then this takes the form of a nontaxable return of capital. ${ }^{11}$ In most cases, E\&P and taxable income are likely to be similar because, unlike GAAP-to-tax adjustments, differences between tax and E\&P accounting are small. In this sense payments in excess of E\&P are a good proxy for payments in excess of taxable income.

This suggests a strategy for estimating discretionary and nondiscretionary dividends. By multiplying the components of Form 1099-DIV by weighted basic shares outstanding, I can estimate the dollar value of each component. To estimate the amount of dividends required to maintain status, one would simply take $90 \%$ of the ordinary income component. ${ }^{12}$ To estimate the dividends required to eliminate the REIT's corporate income taxes, I sum the ordinary income and capital gains components.

\footnotetext{
${ }^{9}$ Throughout the article I treat qualified dividends as being part of ordinary income. Qualified dividends are quite rare in the REIT context and small in magnitude and typically are generated by dividend income the REIT receives. Unrecaptured Section 1250 gains (what is typically termed depreciation recapture in real estate valuation) are treated as a part of capital gains.

${ }^{10}$ Notice that the capital gains dividend is not literally paid with cash from the sale of properties. When the REIT realizes a capital gain, it can elect to treat part of the dividend it pays as a capital gains dividend. So, although cash flows from the sale of a property and capital gains are likely to be positively related, the amount of the capital gains dividend is determined by the capital gain not the cash flow from the transaction.

${ }^{11}$ A nontaxable return of capital reduces the tax basis the investor has in the REIT. In this sense the investor still faces future capital gains tax but has the ability to time when it is realized.

${ }^{12}$ Or $95 \%$ prior to 2001.
} 
The Appendix provides a detailed discussion of my method and also compares it to the method proposed by Hardin and Hill (2008) using the example of AMB Corporation.

\section{Discretionary and Nondiscretionary Dividends}

NAREIT has an extensive database of the taxable makeup of each REIT's dividends. The database is fairly comprehensive in terms of the cross-section of REITs and spans the period 1997-2007. ${ }^{13}$ I fill gaps in these data by examining REIT annual reports and individual REIT Investor Relation Web pages. ${ }^{14}$

Table 1 reports descriptive statistics for the taxable components of REIT dividends as a percentage of total dividends. ${ }^{15}$ Because of data limitations the cross section of firms is quite small in 1997 and 1998, but from 1999 on the sample has between 64 and 97 firms per year. On average a firm is in the sample for 7 years with the minimum number of years being 1 and the maximum being 11 .

An examination of Table 1 shows several facts. First, the ordinary income component makes up $70 \%$ of the dividend on average, whereas the capital gains and nontaxable return of capital components make up $11 \%$ and $18 \%$, respectively. Second, the weighting on the components changes through time. During the sample period, the ordinary income component has declined while the capital gains component has increased. ${ }^{16}$ Finally, the makeup of dividends varies across firms. Although on average the ordinary income component is the largest dividend component, it is not uncommon to find firms in the sample that pay dividends that are completely capital gains or nontaxable returns of capital in any given year. The fact that there is both time-series and cross-sectional variation in the dividend components suggests that REITs do show some dynamic dividend payout behavior.

\footnotetext{
${ }^{13}$ NAREIT has data going back to 1995 , but matching this sample to other data sources leaves a very limited sample of firms in 1995 and 1996.

${ }^{14}$ Another potential source for this data is the dividend file in the Center for Research in Security Prices (CRSP). CRSP provides distribution codes that identify the taxable makeup of a dividend. Comparing the data from NAREIT to the data from CRSP, it is apparent that CRSP inaccurately treats virtually all REIT dividends as ordinarily taxable cash distributions. As such it is not a viable source of data for this study.

${ }^{15}$ Throughout the study I examine only regular dividends. Compared to $\mathrm{C}$ corporations, REITs pay special dividends quite frequently. An examination of annual reports and Form 1099-DIV disclosures reveal there is an almost mechanical explanation for special dividends. Because net capital gains are taxed at a $35 \%$ marginal tax rate, REITs have a large tax incentive to distribute them in dividends. If a REIT conducts a large portfolio sale (and thus incurs large net capital gains) it would want to distribute these gains in dividends to avoid paying tax. Because distributing these dividends is a large one-off event, they are labeled as special dividends. The effect of only examining regular dividends is to reduce the total percentage of capital gains distributions and to also decrease the total dividend yield observed.

${ }^{16}$ The relative increase in the capital gains component is to be expected given that the majority of the sample period corresponds to a bull real estate market. In such an environment it is to be expected that REITs will incur large capital gains when they sell properties and, given their tax motivation, they will pass these through to investors.
} 


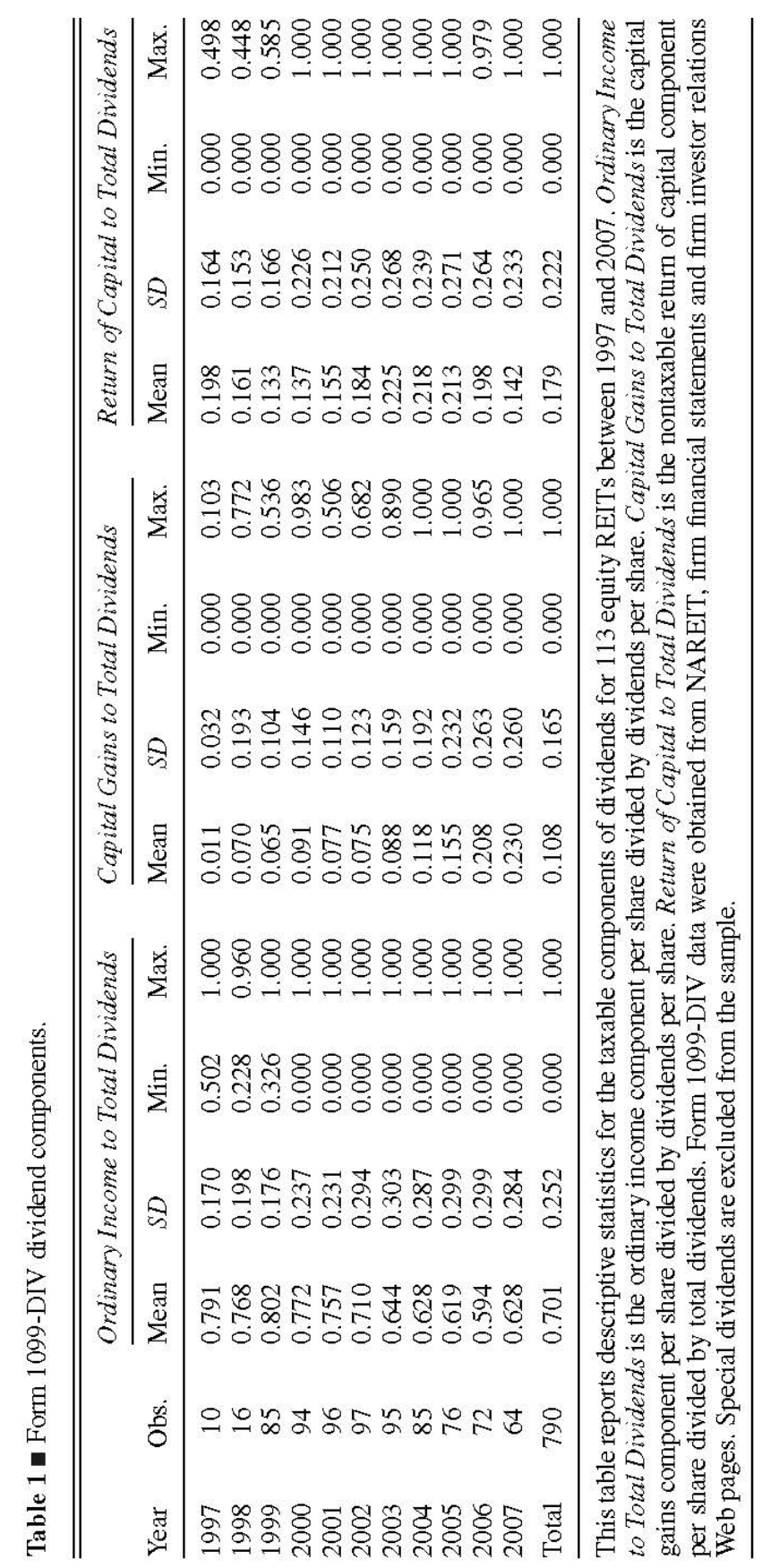

Table 2 reports the dividend components as a percentage of total assets. To calculate the dollar value of total dividends and the dividend components, I multiply the per-share values by weighted basic shares. To make the dollar values comparable across firms, I scale each by last period's total assets.

On average REITs pay dividends equal to $4.5 \%$ of total assets. The minimum dividend yield I observe in the sample is $0 \%$ and the maximum is $15.4 \%$. The high numbers for the dividend yield are not unexpected given the high yield nature of the REIT industry. 
Table 3 reports descriptive statistics for the two proposed measures of discretionary dividends.

Panel A reports statistics for discretionary dividends defined as dividends in excess of the dividends required to eliminate the REIT's federal income tax. These are reported both as a percentage of total dividends and as a percentage of total assets. Panel B reports statistics for discretionary dividends, defined as dividends in excess of the level required to maintain REIT status. Once again these are reported both as a percentage of total dividends and as a percentage of total assets.

Table 2 a Dividends to total assets.

\begin{tabular}{|c|c|c|c|c|c|c|c|c|c|}
\hline \multicolumn{10}{|c|}{ Panel A: Total dividends and ordinary income } \\
\hline \multirow[b]{2}{*}{ Year } & \multirow[b]{2}{*}{ Obs. } & \multicolumn{4}{|c|}{ Total Dividends to Total Assets } & \multicolumn{4}{|c|}{ Ordinary Income to Total Assets } \\
\hline & & Mean & $S D$ & Min. & Max. & Mean & $S D$ & Min. & Max. \\
\hline 1997 & 10 & 0.069 & 0.019 & 0.035 & 0.105 & 0.055 & 0.022 & 0.035 & 0.105 \\
\hline 1998 & 16 & 0.053 & 0.014 & 0.035 & 0.082 & 0.042 & 0.017 & 0.011 & 0.079 \\
\hline 1999 & 85 & 0.042 & 0.014 & 0.016 & 0.079 & 0.034 & 0.015 & 0.007 & 0.074 \\
\hline 2000 & 94 & 0.040 & 0.014 & 0.012 & 0.092 & 0.032 & 0.016 & 0 & 0.085 \\
\hline 2001 & 96 & 0.041 & 0.016 & 0 & 0.107 & 0.032 & 0.017 & 0 & 0.104 \\
\hline 2002 & 97 & 0.041 & 0.019 & 0 & 0.119 & 0.031 & 0.020 & 0 & 0.116 \\
\hline 2003 & 95 & 0.042 & 0.021 & 0 & 0.136 & 0.030 & 0.021 & 0 & 0.115 \\
\hline 2004 & 85 & 0.044 & 0.023 & 0 & 0.154 & 0.030 & 0.023 & 0 & 0.116 \\
\hline 2005 & 76 & 0.043 & 0.023 & 0 & 0.148 & 0.029 & 0.024 & 0 & 0.131 \\
\hline 2006 & 72 & 0.042 & 0.022 & 0.014 & 0.149 & 0.027 & 0.023 & 0 & 0.131 \\
\hline 2007 & 64 & 0.043 & 0.024 & 0.017 & 0.147 & 0.028 & 0.023 & 0 & 0.132 \\
\hline Total & 790 & 0.045 & 0.019 & 0 & 0.154 & 0.034 & 0.020 & 0 & 0.132 \\
\hline
\end{tabular}

Panel B: Capital gains and return of capital

\begin{tabular}{|c|c|c|c|c|c|c|c|c|c|}
\hline \multirow[b]{2}{*}{ Year } & \multirow[b]{2}{*}{ Obs. } & \multicolumn{4}{|c|}{ Capital Gains to Total Assets } & \multicolumn{4}{|c|}{ Return of Capital to Total Assets } \\
\hline & & Mean & $S D$ & Min. & Max. & Mean & $S D$ & Min. & Max. \\
\hline 1997 & 10 & 0.001 & 0.003 & 0 & 0.008 & 0.013 & 0.011 & 0 & 0.036 \\
\hline 1998 & 16 & 0.004 & 0.009 & 0 & 0.037 & 0.008 & 0.007 & 0 & 0.020 \\
\hline 1999 & 85 & 0.002 & 0.004 & 0 & 0.021 & 0.005 & 0.006 & 0 & 0.026 \\
\hline 2000 & 94 & 0.004 & 0.007 & 0 & 0.046 & 0.005 & 0.008 & 0 & 0.035 \\
\hline 2001 & 96 & 0.003 & 0.005 & 0 & 0.026 & 0.006 & 0.008 & 0 & 0.047 \\
\hline 2002 & 97 & 0.003 & 0.005 & 0 & 0.025 & 0.007 & 0.010 & 0 & 0.045 \\
\hline 2003 & 95 & 0.003 & 0.006 & 0 & 0.035 & 0.009 & 0.011 & 0 & 0.040 \\
\hline 2004 & 85 & 0.005 & 0.009 & 0 & 0.054 & 0.009 & 0.010 & 0 & 0.043 \\
\hline 2005 & 76 & 0.006 & 0.009 & 0 & 0.037 & 0.008 & 0.009 & 0 & 0.031 \\
\hline 2006 & 72 & 0.008 & 0.010 & 0 & 0.050 & 0.007 & 0.009 & 0 & 0.032 \\
\hline 2007 & 64 & 0.009 & 0.011 & 0 & 0.038 & 0.005 & 0.008 & 0 & 0.034 \\
\hline Total & 790 & 0.004 & 0.007 & 0 & 0.054 & 0.008 & 0.009 & 0 & 0.047 \\
\hline
\end{tabular}

This table reports descriptive statistics for the taxable components of dividends for 113 equity REITs between 1997 and 2007. Total Dividends to Total Assets is total dividends paid divided by total assets. Ordinary Income to Total Assets is the ordinary income component per share multiplied by weighted basic shares all divided by total assets. Capital Gains to Total Dividends is the capital gains component per share multiplied by weighted basic shares all divided by total assets. Return of Capital to Total Assets is the nontaxable return of capital component per share multiplied by weighted basic shares all divided by total assets. Form 1099-DIV data were obtained from NAREIT, firm financial statements and firm investor relations Web pages. Total assets and weighted basic shares were obtained from SNL. Special dividends are excluded from the sample. 
On average $17.9 \%$ and $35.1 \%$ of total dividends are discretionary when discretionary dividends are defined as being in excess of the tax elimination and the level required to maintain status, respectively. The fact that excess dividends under tax elimination are smaller is mainly driven by the fact that under this scenario the REIT pays out its taxable capital gains as dividends. As was seen in Table 1, the relative magnitude of capital gains as a percentage of REIT dividends has grown through time. A $t$ test of equal means between the two discretionary dividend definitions is rejected at all standard confidence levels.

When I examine discretionary dividends as a percentage of total assets, I observe a similar pattern to that observed for discretionary dividends as a percentage of total dividends. The mean level of discretionary dividends is much lower under tax elimination $(0.8 \%)$ than under maintaining status (1.5\%). In both cases I observe both cross-sectional and time-series variation in discretionary dividends.

Table 3 a Discretionary dividends.

\begin{tabular}{|c|c|c|c|c|c|c|c|c|c|}
\hline \multicolumn{10}{|c|}{ Panel A: In excess of tax elimination } \\
\hline \multirow[b]{2}{*}{ Year } & \multirow[b]{2}{*}{ Obs. } & \multicolumn{4}{|c|}{$\begin{array}{l}\text { Discretionary Dividends to Total } \\
\text { Dividends }\end{array}$} & \multicolumn{4}{|c|}{$\begin{array}{l}\text { Discretionary Dividends to Total } \\
\text { Assets }\end{array}$} \\
\hline & & Mean & $S D$ & Min. & Max. & Mean & $S D$ & Min. & Max. \\
\hline 1997 & 10 & 0.198 & 0.164 & 0 & 0.498 & 0.013 & 0.011 & 0 & 0.036 \\
\hline 1998 & 16 & 0.161 & 0.153 & 0 & 0.448 & 0.008 & 0.007 & 0 & 0.020 \\
\hline 1999 & 85 & 0.133 & 0.166 & 0 & 0.585 & 0.005 & 0.006 & 0 & 0.026 \\
\hline 2000 & 94 & 0.137 & 0.226 & 0 & 1 & 0.005 & 0.008 & 0 & 0.035 \\
\hline 2001 & 96 & 0.155 & 0.212 & 0 & 1 & 0.006 & 0.008 & 0 & 0.047 \\
\hline 2002 & 97 & 0.184 & 0.250 & 0 & 1 & 0.007 & 0.010 & 0 & 0.045 \\
\hline 2003 & 95 & 0.225 & 0.268 & 0 & 1 & 0.009 & 0.011 & 0 & 0.040 \\
\hline 2004 & 85 & 0.218 & 0.239 & 0 & 1 & 0.009 & 0.010 & 0 & 0.043 \\
\hline 2005 & 76 & 0.213 & 0.271 & 0 & 1 & 0.008 & 0.009 & 0 & 0.031 \\
\hline 2006 & 72 & 0.198 & 0.264 & 0 & 0.979 & 0.007 & 0.009 & 0 & 0.032 \\
\hline 2007 & 64 & 0.142 & 0.233 & 0 & 1 & 0.005 & 0.008 & 0 & 0.034 \\
\hline Total & 790 & 0.179 & 0.222 & 0 & 1 & 0.008 & 0.009 & 0 & 0.047 \\
\hline
\end{tabular}


Table 3 a continued

\begin{tabular}{|c|c|c|c|c|c|c|c|c|c|}
\hline \multicolumn{10}{|c|}{ Panel B: In excess of maintaining status } \\
\hline \multirow[b]{2}{*}{ Year } & \multirow[b]{2}{*}{ Obs. } & \multicolumn{4}{|c|}{$\begin{array}{l}\text { Discretionary Dividends to Total } \\
\text { Dividends }\end{array}$} & \multicolumn{4}{|c|}{$\begin{array}{l}\text { Discretionary Dividends to Total } \\
\text { Assets }\end{array}$} \\
\hline & & Mean & $S D$ & Min. & Max. & Mean & $S D$ & Min. & Max. \\
\hline 1997 & 10 & 0.249 & 0.161 & 0.050 & 0.523 & 0.017 & 0.012 & 0.002 & 0.038 \\
\hline 1998 & 16 & 0.270 & 0.188 & 0.088 & 0.784 & 0.014 & 0.009 & 0.004 & 0.037 \\
\hline 1999 & 85 & 0.238 & 0.167 & 0.050 & 0.690 & 0.009 & 0.007 & 0.001 & 0.028 \\
\hline 2000 & 94 & 0.267 & 0.225 & 0.050 & 1 & 0.010 & 0.009 & 0.001 & 0.047 \\
\hline 2001 & 96 & 0.308 & 0.198 & 0 & 1 & 0.012 & 0.008 & 0 & 0.047 \\
\hline 2002 & 97 & 0.330 & 0.246 & 0 & 1 & 0.013 & 0.010 & 0 & 0.045 \\
\hline 2003 & 95 & 0.378 & 0.256 & 0 & 1 & 0.015 & 0.011 & 0 & 0.050 \\
\hline 2004 & 85 & 0.399 & 0.246 & 0 & 1 & 0.017 & 0.011 & 0 & 0.055 \\
\hline 2005 & 76 & 0.429 & 0.266 & 0 & 1 & 0.017 & 0.010 & 0 & 0.038 \\
\hline 2006 & 72 & 0.466 & 0.269 & 0.100 & 1 & 0.018 & 0.010 & 0.002 & 0.052 \\
\hline 2007 & 64 & 0.435 & 0.255 & 0.100 & 1 & 0.017 & 0.011 & 0.003 & 0.050 \\
\hline Total & 790 & 0.351 & 0.225 & 0 & 1 & 0.015 & 0.010 & 0 & 0.055 \\
\hline
\end{tabular}

This table reports descriptive statistics for the two discretionary dividend measures proposed in the article. The sample is 113 equity REITs between 1997 and 2007. Panel A reports statistics where the benchmark nondiscretionary dividend level is the level that eliminates income taxes. In this case the discretionary dividends are the nontaxable return of capital component from Form 1099-DIV. Panel B reports statistics where the benchmark nondiscretionary dividend level is the level that enables the REIT to maintain REIT status. In this case discretionary dividends are $10 \%$ (5\% prior to 2001 ) of the ordinary income component plus the capital gains component from Form 1099-DIV. To calculate Discretionary Dividends to Total Dividends the respective discretionary dividend per share is divided by total dividends. To calculate discretionary dividends to total assets, the discretionary dividend per share is multiplied by weighted basic shares and then divided by total assets. Form 1099-DIV data were obtained from NAREIT, firm financial statements and firm investor relations Web pages. Total assets and weighted basic shares were obtained from SNL. Special dividends are excluded from the sample.

\section{Testing Dividend Payout Theories}

Prior studies suggest that the dividend payout policy of REITs could be the result of agency costs, signaling, dividend catering or capital market considerations. Following Bradley, Capozza and Seguin (1998) and Hardin and Hill (2008), the methodology I employ to test these theories is to estimate Tobit models with discretionary dividend payments as the dependent variable and variables that proxy for the dividend payout theories as independent variables. What differentiates this study from earlier studies is that I can accurately measure the discretionary component of the REIT's dividend. Because dividend payout theories relate to a manager's decision, accurately measuring the manager's decision should give this study greater power to test the competing theories. 


\section{Explanatory Variables}

I rely heavily on the prior literature to identify variables to proxy for dividend payout theories. In this regard I appeal to the arguments of Wang, Erikson and Gau (1993), Bradley, Capozza and Seguin (1998) and Hardin and Hill (2008) in selecting logical proxies for each theory. Unless otherwise stated, all data were obtained from SNL.

Bradley, Capozza and Seguin (1998) argue that a REIT's dividend policy is the outcome of either an agency cost model or a dividend signaling model. Agency cost models argue that when faced with high asymmetric information the firm will pay more of its cash flow in dividends. Under signaling models the firm uses its dividend policy to signal future cash flow expectations. In both cases higher expected future cash flows should lead to higher dividends. Bradley, Capozza and Seguin's (1998) main insight was that the models have opposite predictions for cash flow volatility. Firms with high cash flow volatility should have a conservative dividend policy under signaling models because the firm faces high costs for cutting dividends. However, under agency costs, firms with high cash flow volatility should also face high asymmetric information and would be more inclined to have an aggressive dividend payout policy.

To control for expected future cash flows, I appeal to the rational expectations argument of Bradley, Capozza and Seguin (1998) and include Excess FFO and change in Excess FFO. Excess FFO is last period's funds from operations (FFO) minus last period's nondiscretionary dividend divided by last period's total assets. The change in Excess FFO is current period Excess FFO minus last period's Excess FFO, divided by current period total assets. In each case the definition of nondiscretionary dividends matches the dependent variable used in the estimation (i.e., $90 \%$ of the ordinary income component when considering maintaining status and the sum of the ordinary income and capital gains components when considering the tax-eliminating dividend level).

Under either agency models or signaling models, I expect a positive relationship between the payment of discretionary dividends and both the level and change of Excess FFO.

To incorporate ex ante cash flow volatility I include annual property type and location Herfindahl indexes. Bradley, Capozza and Seguin (1998) argue that REITs with properties that are more diversified by location or property type should have more stable cash flows. SNL reports property details for a REIT's property portfolio. The location Herfindahl index is $\sum_{r=1}^{9} S_{r}{ }^{2}$, where $S_{r}$ is the proportion of the firm's properties in each NCREIF region (Northeast, Mideast, Southeast, East North Central, West North Central, Southwest, Mountain, Pacific and Not Available). The type Herfindahl index is $\sum_{r=1}^{8} S_{r}{ }^{2}$, where $S_{r}$ is the proportion of the firm's properties in each property type (Office, Industrial, Retail, Self-Storage, 
Hotel, Residential, Multi-Use, Specialty.) Thus, a Herfindahl index of 1 indicates a completely concentrated portfolio, while an equally weighted portfolio would produce a Herfindahl index of 0.11 for location and 0.125 for type.

Bradley, Capozza and Seguin (1998) also argue that firm leverage should impact the firm's decision to pay dividends. There are two possible explanations for the relation between dividends and leverage. First, firm leverage may proxy for higher cash flow uncertainty. Second, firms facing high agency costs may use leverage as a means of reducing discretionary cash flows. To capture these effects I include Leverage, the firm's total debt plus preferred stock divided by market capitalization plus total debt and preferred stock. I expect a negative relationship between Leverage and the payment of discretionary dividends.

Hardin and Hill (2008) argue that REIT dividend policy may be the result of asymmetric information. Firms that face lower asymmetric information should have better access to capital markets and be less constrained in paying dividends. They use Tobin's $Q$ as a potential proxy for asymmetric information. Firms with high Tobin's $Q$ should face lower asymmetric information and subsequently be less constrained in their ability to pay discretionary dividends. A positive relationship is expected between the payment of discretionary dividends and Tobin's $Q$. Tobin's $Q$ is measured as the sum of the firm's market capitalization, total debt and preferred stock divided by total assets.

Hardin and Hill (2008) argue that firms with high financial performance should be allowed by the capital markets to retain some of their cash flow to fund future investment. In this sense good financial performance demonstrates the manager's ability to be a good steward of capital. To capture this effect, I include Return on Assets. Return on Assets is measured as net income available to shareholders dividend by total assets. I expect a negative relationship between discretionary dividends and Return on Assets.

Firms can return invested capital to investors through either higher dividends or stock repurchases. Although there is an extensive literature on REIT repurchase behavior (see, e.g., Giambona, Giaccotto and Sirmans 2005, Hartzell, Sun and Titman 2005, Adams, Brau and Holmes 2007, Boudry, Kallberg and Liu 2009), for the purposes of this study I am mainly concerned that repurchases provide a substitute mechanism for returning invested capital to investors. Following Hardin and Hill (2008), I include Repurchases and change in Repurchases in the estimation. Repurchases is common stock repurchases last period divided by total assets last period. The change in Repurchases is common stock repurchases this year minus common stock repurchases last year divided by this year's total assets. In both cases I expect a negative relationship with discretionary dividends. 
Hardin and Hill (2008) argue that lines of credit and particularly the availability of lines of credit should influence dividend payment. I include Lines of Credit, the amount of the firm's drawn credit lines as a percentage of total credit lines in the estimation. Hardin and Hill's (2008) logic is that lines of credit should create more flexibility for the firm to pay discretionary dividends and one should observe a positive relationship between lines of credit and discretionary dividend payments. A potential confounding effect to this is that many lines of credit agreement have dividend payment limitations in their covenants. The lender protects against the potential of the firm borrowing to pay dividends by restricting the level of dividends that are payable. As such it is unclear in which direction this relationship should go.

I also include Size, the natural log of the firm's market capitalization. Firm size could proxy for a number of factors. All else equal, larger REITs are likely to have more diversified cash flows, suggesting lower ex ante cash flow volatility. Boudry, Kallberg and Liu (2011) also show that firm size is a key determinant of analyst coverage. This suggests that larger firms should have lower asymmetric information and greater access to the capital markets.

In addition to the variables suggested by Wang, Erikson and Gau (1993), Bradley, Capozza and Seguin (1998) and Hardin and Hill (2008), I include four other variables related to dividend policy. Lintner (1956) argues that firms smooth their dividends to meet a target payout ratio. Under this assumption, it is logical to expect that managers may use discretionary dividends to meet a target payout ratio. If this is true, all else equal, I would expect to see REITs pay lower discretionary dividends when current nondiscretionary dividends are high, because paying discretionary dividends on top of an already high nondiscretionary dividend is likely to result in a payout ratio that exceeds the target. A similar logic holds for changes in nondiscretionary payouts. Firms that experience large increases in nondiscretionary dividends are less likely to pay discretionary dividends.

I capture these effects using two variables. The first is Nondiscretionary Dividends to Total Assets, which is the dollar value of nondiscretionary dividends this period divided by last period's total assets. The second is Change in Nondiscretionary Dividends to Total Assets, which is the change in nondiscretionary dividend between the current period and last period, dividend by last period's total assets. In each case I match the nondiscretionary benchmark (tax elimination or maintaining status to the dependent variable in the analysis). 
Third, to proxy for capital market access I include Rated, a dummy variable equal to one if the firm has S\&P-rated debt outstanding. ${ }^{17}$ All else equal, a credit rating indicates greater access to the capital markets. Credit ratings data was obtained from COMPUSTAT.

Finally, Baker and Wurgler (2004) argue that firms cater their dividends to the capital markets. That is, they pay dividends when the market values them more. To capture this catering incentive I include Dividend Premium, the log difference between the average market to book ratios of dividendand non-dividend-paying firms. ${ }^{18}$ Baker and Wurgler (2004) exclude REITs when calculating the Dividend Premium, so this measure is a general market effect. If it holds for REITs as well, I would expect a positive relationship between the Dividend Premium and payment of discretionary dividends.

Table 4 reports descriptive statistics for the independent variables in the analysis. Excess FFO and the change in Excess FFO average $2.9 \%$ and $0.2 \%$, respectively, when the nondiscretionary benchmark is tax elimination. As expected, they are slightly higher at $3.5 \%$ and $0.3 \%$ when the benchmark is maintaining status.

Under the tax-eliminating benchmark, Nondiscretionary Dividends and the change in Nondiscretionary Dividends average $3.3 \%$ and $0.3 \%$, respectively. As expected, they are slightly lower under the maintaining status benchmark with average values of $2.8 \%$ and $0.2 \%$, respectively.

Repurchases averages $0.4 \%$, whereas change in Repurchases averages $0.1 \%$. These figures are very similar to the numbers reported in Hardin and Hill (2008).

On average $53.7 \%$ of firm years in the sample are observations where the firm has a credit rating and in the average firm year the firm's lines of credit are $41.1 \%$ drawn. The average Tobin's $Q$ in the sample is 1.2, which is very close to the average reported by Hardin and Hill (2008).

The location and type Herfindahl indexes show that REITs tend to be more concentrated by type than location. In both cases the maximum and minimum Herfindahl indexes show that there are firms in the sample that are completely focused by type or location (an index of one) and REITs that are almost completely diversified.

\footnotetext{
${ }^{17}$ There is very little dispersion in credit ratings in the data with most REITs having an investment-grade rating of $B B B$, with very few reaching the A- level.

${ }^{18}$ I construct this variable using COMPUSTAT data following the method of Baker and Wurgler (2004). I was unable to exactly match their result, although the correlation between my Dividend Premium and theirs is $98 \%$.
} 
Table 4 a Descriptive statistics.

\begin{tabular}{lcccrc}
\hline \hline Variable & Obs. & Mean & \multicolumn{1}{l}{$S D$} & \multicolumn{1}{l}{ Min. } & \multicolumn{1}{c}{ Max. } \\
\hline Excess FFO & 790 & 0.029 & 0.017 & -0.088 & 0.110 \\
$\Delta$ Excess FFO & 790 & 0.002 & 0.015 & -0.147 & 0.122 \\
Excess FFO (Status) & 790 & 0.035 & 0.017 & -0.081 & 0.117 \\
$\Delta$ Excess FFO (Status) & 790 & 0.003 & 0.015 & -0.146 & 0.123 \\
Nondisc. Dividends & 790 & 0.033 & 0.019 & 0.000 & 0.132 \\
$\Delta$ Nondisc. Dividends & 790 & 0.003 & 0.010 & -0.040 & 0.049 \\
Nondisc. Dividends (Status) & 790 & 0.028 & 0.018 & 0.000 & 0.119 \\
$\Delta$ Nondisc. Dividends (Status) & 790 & 0.002 & 0.009 & -0.045 & 0.041 \\
Repurchases & 790 & 0.004 & 0.011 & 0.000 & 0.154 \\
$\Delta$ Repurchases & 790 & 0.001 & 0.014 & -0.139 & 0.122 \\
Rated (Yes $=1$ ) & 790 & 0.537 & 0.499 & 0.000 & 1.000 \\
Lines of Credit & 790 & 0.411 & 0.290 & 0.000 & 1.000 \\
$Q$ & 790 & 1.200 & 0.323 & 0.302 & 2.975 \\
Location Herfindahl & 790 & 0.439 & 0.280 & 0.129 & 1.000 \\
Type Herfindahl & 790 & 0.820 & 0.224 & 0.254 & 1.000 \\
Size (in millions) & 790 & 1665 & 2216 & 1.860 & 16492 \\
Leverage & 790 & 0.444 & 0.152 & 0.000 & 0.973 \\
Return on Assets & 790 & 0.031 & 0.030 & -0.102 & 0.389 \\
Dividend Premium & 790 & -0.086 & 0.048 & -0.196 & -0.009 \\
\hline
\end{tabular}

This table reports descriptive statistics for the independent variables in the analysis. Excess $F F O$ is the firm's funds from operations last year less last year's nondiscretionary dividend, divided by last year's total assets. $\triangle$ Excess $F F O$ is the change in Excess FFO divided by total assets. Nondiscretionary Dividends is the ordinary income and capital gains components multiplied by weighted basic shares, all divided by total assets. $\Delta$ Nondiscretionary Dividends is the change in Nondiscretionary Dividends divided by total assets. Repurchases is common stock repurchases divided by total assets (in percentage). $\Delta$ Repurchases is the change in common stock repurchases divided by total assets (in percentage). Rated is a dummy variable equal to one if the firm has debt rated by S\&P. Lines of Credit is the ratio of lines of credit drawn to total lines of credit. $Q$ is market capitalization plus total debt and preferred stock divided by total assets. Location Herfindahl is a Herfindahl index based on the location of the firm's properties. Type Herfindahl is a Herfindahl index based on the type of the firm's properties. Size is the firm's market capitalization in millions. Leverage is the ratio of total debt divided by total debt plus preferred stock plus market capitalization. Return on Assets is net income available to common shareholders divided by total assets. Dividend Premium is the log difference between the average market to book ratio of dividend and nondividend-paying firms. For Excess FFO and Nondiscretionary Dividends, Status refers to the case where the nondiscretionary benchmark is $90 \%$ (or $95 \%$ before 2001) of the ordinary income component.

The size of the firms in the sample varies quite markedly, with the smallest being $\$ 1.86$ million, the largest $\$ 16.5$ billion and the average firm having a market capitalization of $\$ 1.6$ billion. Although these numbers are larger than those reported by Hardin and Hill (2008), this reflects that fact that my sample ends 2 years after their sample and REITs demonstrated considerable growth over the period. Overall, the numbers suggest that the sample is a fairly representative cross-section of the REIT universe.

The leverage of the firms in the sample averages $44.4 \%$, with a maximum of $97.3 \%$ and a minimum of zero. The average Return on Assets in the sample is $3.1 \%$. 
Baker and Wurgler (2004) calculate the dividend premium from 1962 to 2000 . A noticeable feature of their measure is that there are long periods of dividend premium and long periods of a dividend discount. During my sample period it appears that there was a dividend discount, with the average premium being $-9 \%$. However, there does appear to be variation to this number.

Table 5 reports pairwise correlations between the independent variables. As expected, Nondiscretionary Dividends has moderate correlations with Return on Assets, Leverage and Q. Size and Rated also have a moderate correlation of $57 \%$.

\section{Estimation Results}

I examine REIT dividend payout decisions in two sets of estimations. The first set of results reported in Table 6 is for the random effects Tobit estimation of Discretionary Dividends to Total Assets on the independent variables, where discretionary dividends are defined as the dividends in excess of those required to eliminate corporate income taxes. The second set of results is reported in Table 7. Table 7 reports random effects Tobit estimation results of Discretionary Dividends to Total Assets on the independent variables, where discretionary dividends are defined as the dividends in excess of those required for the REIT to maintain REIT status. In each case I use a Tobit specification because the dependent variable is censored at zero. In such circumstances it is inappropriate to use ordinary least squares (OLS). To aid interpretation of the model, marginal effects are reported for the change in the unconditional expected value of Discretionary Dividends to Total Assets for a one-standard-deviation increase in the independent variables. I also report this same marginal effect as a percentage of the average value of the dependent variable. For dummy variables, the marginal effect is calculated for a change from zero to one.

Several results are apparent in Table 6. First, as expected, higher cash flow has a significant positive marginal effect on the payment of discretionary dividends. A one-standard-deviation increase in Excess FFO leads to a 14.5-basis-points increase in discretionary dividends as a percentage of total assets. This is equal to approximately $20.65 \%$ of the average level of discretionary dividends I observe in the sample. Similarly, change in Excess FFO also has a significant positive marginal effect on the payment of discretionary dividends. 


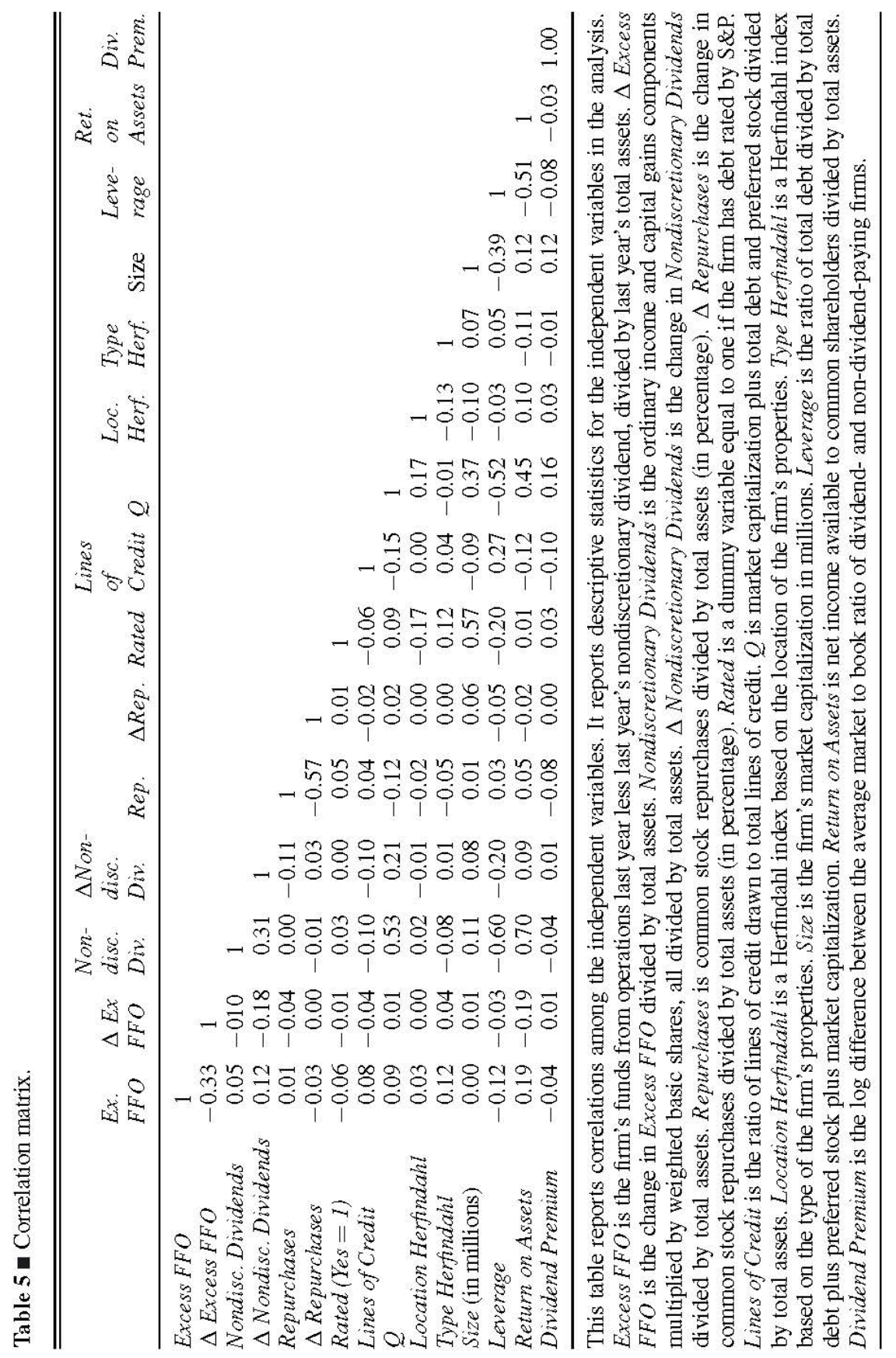


Table 6 - Tobit estimation results (dividends in excess of tax elimination).

\begin{tabular}{lccr}
\hline \hline Variable & Marginal Effect & $\begin{array}{l}\text { Marginal Effect } \\
\text { (\% of mean) }\end{array}$ & \multicolumn{1}{c}{$Z$} \\
\hline Excess FFO & 0.145 & 20.65 & 5.89 \\
$\Delta$ Excess FFO & 0.071 & 10.14 & 4.28 \\
Nondiscretionary Dividends & -0.348 & -49.62 & -10.26 \\
$\Delta$ Nondiscretionary Dividends & -0.126 & -17.97 & -8.07 \\
Repurchases & -0.058 & -8.30 & -2.93 \\
$\Delta$ Repurchases & -0.034 & -4.88 & -1.98 \\
Rated (Yes $=1)$ & -0.052 & -7.42 & -0.89 \\
Lines of Credit & 0.006 & 0.91 & 0.41 \\
$Q$ & 0.103 & 14.73 & 3.44 \\
Location Herfindahl & -0.066 & -9.43 & -2.66 \\
Type Herfindahl & -0.001 & -0.10 & -0.03 \\
Size (in millions) & -0.112 & -16.00 & -3.09 \\
Leverage & -0.118 & -16.82 & -3.99 \\
Return on Assets & 0.022 & 3.16 & 0.99 \\
Dividend Premium & 0.020 & 2.82 & 1.64 \\
Obs. & 790 & & \\
Left Censored & 317 & & \\
$\rho$ & 0.72 & & \\
$\chi^{2}$ ( $\left.\rho=0\right)$ & 365 & & \\
\hline
\end{tabular}

This table reports marginal effects for the random effects Tobit estimation of Discretionary Dividends to Total Assets on independent variables. The marginal effect is interpreted as the change in Discretionary Dividends to Total Assets for a one-standarddeviation increase in the independent variable. For dummy variables it is for a change from zero to one. Excess FFO is the firm's funds from operations last year less last year's nondiscretionary dividend, divided by last year's total assets. $\triangle$ Excess $F F O$ is the change in Excess FFO divided by total assets. Nondiscretionary Dividends is the ordinary income and capital gains components multiplied by weighted basic shares, all divided by total assets. $\Delta$ Nondiscretionary Dividends is the change in $N$ ondiscretionary Dividends divided by total assets. Repurchases is common stock repurchases divided by total assets (as a percentage). $\Delta$ Repurchases is the change in common stock repurchases divided by total assets (as a percentage). Rated is a dummy variable equal to one if the firm has debt rated by S\&P. Lines of Credit is the ratio of lines of credit drawn to total lines of credit. $Q$ is market capitalization plus total debt and preferred stock divided by total assets. Location Herfindahl is a Herfindahl index based on the location of the firm's properties. Type Herfindahl is a Herfindahl index based on the type of the firm's properties. Size is the firm's market capitalization in millions. Leverage is the ratio of total debt divided by total debt plus preferred stock plus market capitalization. Return on Assets is net income available to common shareholders divided by total assets. Dividend Premium is the $\log$ difference between the average market to book ratio of dividendand non-dividend-paying firms. $\rho$ is the percent contribution to total variance of the panel-level variance component. If $\rho$ equals zero, then pooled and panel estimators are identical. 
Table 7 - Tobit estimation results (dividends in excess of maintaining status).

\begin{tabular}{lccr}
\hline \hline Variable & Marginal Effect & $\begin{array}{l}\text { Marginal Effect } \\
\text { (\% of Mean) }\end{array}$ & \multicolumn{1}{c}{$Z$} \\
\hline Excess FFO & 0.162 & 14.16 & 4.84 \\
$\Delta$ Excess FFO & 0.124 & 10.83 & 5.58 \\
Nondiscretionary Dividends & -0.437 & -38.31 & -9.53 \\
$\Delta$ Nondiscretionary Dividends & -0.143 & -12.50 & -5.94 \\
Repurchases & -0.053 & -4.63 & -2.13 \\
$\Delta$ Repurchases & -0.028 & -2.45 & -1.28 \\
Rated (Yes 1 ) & -0.090 & -7.84 & -1.08 \\
Lines of Credit & -0.006 & -0.54 & -0.28 \\
$Q$ & 0.237 & 20.75 & 5.75 \\
Location Herfindaht & 0.009 & 0.79 & 0.26 \\
Type Herfindahl & -0.006 & -0.55 & -0.17 \\
Size (in millions) & -0.110 & -9.62 & -2.15 \\
Leverage & -0.137 & -12.04 & -3.16 \\
Return on Assets & 0.109 & 9.56 & 1.44 \\
Dividend Premium & 0.026 & 2.25 & \\
Obs. & 790 & & \\
Left Censored & 12 & & \\
$\rho$ & 0.59 & & \\
$\chi^{2}$ ( $\rho$ = 0) & 293.4 & & \\
\hline
\end{tabular}

This table reports marginal effects for the random effects Tobit estimation of Discretionary Dividends to Total Assets on independent variables. The marginal effect is interpreted as the change in Discretionary Dividends to Total Assets for a one standard deviation increase in the independent variable. For dummy variables it is for a change from zero to one. Excess FFO is the firm's funds from operations last year less last year's nondiscretionary dividend, divided by last year's total assets. $\triangle$ Excess FFO is the change in Excess FFO divided by total assets. Nondiscretionary Dividends is $90 \%$ (95\% prior to 2001) of the ordinary income component multiplied by weighted basic shares, all divided by total assets. $\Delta$ Nondiscretionary Dividends is the change in Nondiscretionary Dividends divided by total assets. Repurchases is common stock repurchases divided by total assets (as a percentage). $\Delta$ Repurchases is the change in common stock repurchases divided by total assets (as a percentage). Rated is a dummy variable equal to one if the firm has debt rated by S\&P. Lines of Credit is the ratio of lines of credit drawn to total lines of credit. $Q$ is market capitalization plus total debt and preferred stock divided by total assets. Location Herfindahl is a Herfindahl index based on the location of the firm's properties. Type Herfindaht is a Herfindahl index based on the type of the firm's properties. Size is the firm's market capitalization in millions. Leverage is the ratio of total debt divided by total debt plus preferred stock plus market capitalization. Return on Assets is net income available to common shareholders divided by total assets. Dividend Premium is the $\log$ difference between the average market to book ratio of dividend- and non-dividend-paying firms. $\rho$ is the percent contribution to total variance of the panel-level variance component. If $\rho$ equals zero then pooled and panel estimators are identical.

Second, consistent with the arguments of Lintner (1956), there appears to be strong evidence that REITs use discretionary dividends to adjust toward a target level of total dividends. Both Nondiscretionary Dividends and the change in Nondiscretionary Dividends have significantly negative marginal effects. Controlling for cash flows, firms that pay high nondiscretionary dividends pay lower discretionary dividends. The order of magnitude of the effect is quite large. A one-standard-deviation increase in Nondiscretionary Dividends is associated with a 34.8-basis-point decrease in discretionary dividends as a percentage of total assets. This implies an almost a 50\% decrease from the average level I 
observe in the sample. It is also easily the most economically and statistically significant effect in the estimation. The average level of discretionary dividends in excess of tax elimination is approximately \$24 million. A 50\% decline implies a reduction in discretionary dividends of $\$ 12$ million.

Third, consistent with Hardin and Hill (2008), I find that repurchases act as a substitute for discretionary dividends. Both the level and change in Repurchases have significant negative marginal effects. The economic magnitude of the effect is quite small, with a one-standard-deviation increase in Repurchases decreasing the level of discretionary dividends as a percentage of total assets by 5.8 basis points.

Fourth, supporting the results of Bradley, Capozza and Seguin (1998), I find a significantly negative marginal effect for the location Herfindahl index. Firms with more geographically concentrated portfolios appear to pay lower discretionary dividends. If one views location concentration as a proxy for volatility, then this would provide support for the market-signaling hypothesis.

Fifth, capital markets access appears to have a positive marginal effect on the payment of discretionary dividends. $Q$ has a significant positive marginal effect in the estimation.

Finally, I do not find strong evidence supporting the dividend catering arguments of Baker and Wurgler (2004). Although the marginal effect on Dividend Premium is positive, it is not significant at conventional levels of significance.

I present my second set of estimation results in Table 7. In Table 7 I replicate the estimation of Table 6, except in this case the dependent variable is Discretionary Dividends to Total Assets, where nondiscretionary dividends are defined as the level of dividends that is required for the REIT to maintain status.

The results in Table 7 are consistent with the results reported in Table 6. Once again, cash flow has a positive marginal effect on discretionary dividends, whereas the level and change in nondiscretionary dividends has a negative marginal effect. In this estimation a one-standard-deviation increase in Nondiscretionary Dividends is associated with a 43.7-basis-point decrease in discretionary dividends as a percentage of total assets. This implies a 38\% decrease from the average level I observe in the sample. The average level of discretionary dividends in excess of maintaining status is approximately $\$ 45$ million. A 38\% decline implies a reduction in discretionary dividends of \$17 million. It is comforting that both potential definitions of discretionary dividends provide consistent evidence regarding dividend payout policy. 


\section{Conclusion}

This article proposes a new metric for measuring the discretionary component of a REIT's dividend. Unlike prior methods, the method proposed in this article is based on tax disclosures rather than GAAP disclosures. Starting with tax rather than GAAP disclosures eliminates the large GAAP-to-tax adjustments that are inherent in other methods.

For a sample of 113 equity REITs between 1997 and 2007, I find consistent with the commonly held assumption that REITs do on average pay discretionary dividends. On average between $18 \%$ and $34 \%$ of a REIT's dividend is a discretionary distribution. However, what is interesting is that there is a great deal of time-series and cross-sectional variation to these payments. Some firms never pay discretionary dividends, whereas others pay them every year. Furthermore, the amount of these discretionary dividends varies through time. This suggests that a blanket assumption that REITs always pay discretionary dividends is quite inaccurate.

Examining the motivation behind paying discretionary dividends, I find the main motivation appears to be dividend smoothing. Although cash flow is positively related to discretionary dividends, the payout of nondiscretionary dividends is negatively related to discretionary dividends. If the REIT has a high dividend payout based solely on its nondiscretionary dividends, it pays lower discretionary dividends. Even if the REIT has cash flow it could pay out as discretionary dividends, it tends not to do this if its nondiscretionary dividend payout is already high.

The results of this study show that REITs behave in a similar fashion to regular corporations. The main explanation of their dividend payout policy is dividend smoothing. This result differs from the prior literature which finds a substitution effect with repurchases as the main explanation. These differing results are most likely due to the flawed methodology employed in the prior literature.

\section{References}

Adams, G.L., J. Brau and A. Holmes. 2007. REIT Stock Repurchases: Completion Rates, Long-Run Returns, and the Straddle Hypothesis. Journal of Real Estate Research 29: 115-136.

Allen, F. and R. Michaely. 2003. Payout Policy. G. Constantinedes, M. Harris and R. Schultz, editors. North Holland Handbook of Economics. Elsevier North Holland: Amsterdam, 337-429.

Baker, M. and J. Wurgler. 2004. A Catering Theory of Dividends. The Journal of Finance 59: 1125-1165. Bhattacharya, S. 1979. Imperfect Information, Dividend Policy, and "the Bird in the Hand" Fallacy. Bell Journal of Economics 10: 259-270. 
Boudry, W., J. Kallberg and C. Liu. 2009. Investment Opportunities and Share Repurchases. Working Paper. NYU.

Boudry, W., J. Kallberg and C. Liu. 2011. Analyst Behavior and Underwriter Choice. The Journal of Real Estate Finance and Economics. Forthcoming.

Bradley, M., D. Capozza and P. Seguin. 1998. Dividend Policy and Cash-Flow Uncertainty.

Real Estate Economics 26: 556-580.

Downs, D., Z.Guner and G. Patterson. 2000. Capital Distribution Policy and Information Asymmetry: A Real Estate Market Perspective. The Journal of Real Estate Finance and Economics 21: 235-250.

Easterbrook, F. 1984. Two Agency-Cost Explanations of Dividends. American Economic Review 84: 650659.

Financial Accounting Standards Board. 1992. Accounting for Income Taxes. Statement of Financial Accounting Standards No. 109. Author: Norwalk, CT.

Gentry, W., D. Kemsley and C. Mayer. 2003. Dividend Taxes and Share Prices: Evidence from Real Estate Investment Trusts. The Journal of Finance 58: 261-282.

Giambona, E., C. Giaccotto and C.F. Sirmans. 2005. The Long-Run Performance of REIT Stock Repurchases. Real Estate Economics 33: 351-380.

Gupta, S. and K. Newberry. 1997. Determinants of the Variability in Corporate Effective Tax Rates: Evidence from Longitudinal Data. Journal of Accounting and Public Policy 16: 1-34.

Hanlon, M. 2003. What Can We Infer About a Firm's Taxable Income from Its Financial Statements? National Tax Journal 56: 831-863.

Hardin, W. and M. Hill. 2008. REIT Determinants: Excess Dividends and Capital Markets. Real Estate Economics 36: 349-369.

Hartzell, J.C., L. Sun and S. Titman. 2005. The Effect of Corporate Governance on Investment: Evidence from Real Estate Investment Trusts (REITs). Real Estate Economics 34: 342-376.

Jensen, M. 1986. Agency Costs of Free Cash Flow, Corporate Finance and Takeovers. American Economic Review 76: 323-329.

Lee, C.F. and J.B. Kau. 1987. Dividend Payment Behavior and Dividend Policy of REITs. Quarterly Review of Economics and Business 27: 6-21.

Li, W. and E. Lie. 2006. Dividend Changes and Catering Incentives. Journal of Financial Economics 80 : 293-308.

Li, O. and D. Weber. 2007. The Ex-Day Pricing of Dividends for REITs. Working Paper. University of Connecticut. 
Lintner, J. 1956. Distribution of Incomes of Corporations Among Dividends, Retained Earnings, and Taxes. American Economic Review 46: 97-113.

Lisowsky, P. 2009. Inferring U.S. Tax Liability from Financial Statement Information. Journal of the American Taxation Association 31: 29-63.

Manzon, G., Jr. and G. Plesko. 2002. The Relation between Financial and Tax Reporting Measures of Income. Tax Law Review 55: 175-214.

Miller, M. and K. Rock. 1985. Dividend Policy under Asymmetric Information. The Journal of Finance 40: 1031-1052.

Omer, T., K. Malloy and D. Ziebart. 1991. Measurement of Effective Corporate Tax Rates Using Financial Statement Information. Journal of the American Taxation Association 13: 57-72.

Taube, D. and G. Yungmann. 2001, October 25. Best Financial Practices Disclosure: Disclosing Taxable Income and Income Taxes. NAREIT National Policy Bulletin.

Wang, K., J. Erikson and G. Gau. 1993. Dividend Policies and Dividend Announcement Effects for Real

Estate Investment Trusts. Journal of the American Real Estate and Urban Economics Association 21: 185-201.

\section{Appendix: A Comparison to Hardin and Hill (2008)}

This appendix outlines the differences between the Hardin and Hill (2008) method for calculating discretionary dividends and the method proposed in this article. I use the example of AMB Property Corporation because it is one of the few REITs that make discretionary taxable income disclosures. These disclosures enable a reconciliation to actual taxable income for the two methods. Because actual taxable income disclosures are rare and not uniform across firms, a complete analysis across firms is not possible. The analysis presented does however highlight three important points: (1) even if one ignores GAAP/Tax differences, the Hardin and Hill (2008) method is from an accounting perspective incorrect; (2) the GAAP/Tax adjustments that are inherent in the Hardin and Hill approach can be potentially very large and (3) data sources used in the Hardin and Hill approach can make it impossible to calculate discretionary dividends even for a large well-known firm such as AMB.

Below is reported Footnote 8: Income Taxes from AMB Property Corporation's 2006 10-K. The reconciliation presented from Net Income available to common shareholders to taxable income is a voluntary disclosure not required under GAAP. The reconciliation is similar to the disclosure proposed by NAREIT in their 2001 Best Reporting Practices white paper. The reporting of the dividend components is the same disclosure as made in Form 1099-DIV. This need not be reported in the firm's 10-K, although it 
typically is even if the firm does not report the Net Income to Taxable Income reconciliation. In their 2006 10K, AMB Property Corporation provides a reconciliation of net income to common shareholder to taxable income to common shareholders. The full disclosure they make is similar to that recommended by NAREIT in their 2011 Best Reporting Practices white paper. Table A1 reports the data necessary to calculate taxable income under both the Hardin and Hill (2008) method and the method proposed in this paper.

Table A1 a Income Tax Disclosures for AMB Property Corporation* Table reports income tax disclosures made by AMB Property Corporation in their $200610 \mathrm{~K}$.

\begin{tabular}{|c|c|c|c|}
\hline & 2006 & 2005 & 2004 \\
\hline \multicolumn{4}{|l|}{ Income items } \\
\hline Net Income & $224,072,000$ & $257,807,000$ & $125,471,000$ \\
\hline $\begin{array}{l}\text { Net income available to common } \\
\text { shareholders }\end{array}$ & $209,420,000$ & $250,419,000$ & $118,340,000$ \\
\hline $\begin{array}{l}\text { Taxable income available to } \\
\text { common shareholders }\end{array}$ & $77,999,000$ & $184,679,000$ & $107,058,000$ \\
\hline Income Taxes Paid & 0 & 0 & 0 \\
\hline \multicolumn{4}{|l|}{ Distributions } \\
\hline Ordinary income & 0.53 & 0.5 & 0.78 \\
\hline Capital gains & 0.36 & 1.69 & 0.52 \\
\hline Return of capital & 0.49 & 0 & 0.39 \\
\hline Total distribution & 1.38 & 2.19 & 1.69 \\
\hline Weighted basic common Shares & $87,710,500$ & $84,048,936$ & $82,133,627$ \\
\hline
\end{tabular}

\section{Calculating Taxable Income}

Hardin and Hill (2008) propose calculating taxable income as line item 833 in SNL (Net Income from the Statement of Operations) and add back SNL item 4427 Income Taxes. For 2006, 2005 and 2004, Net Income is $\$ 224,072, \$ 257,807$ and $\$ 125,471$ (in thousands), respectively. Income Taxes were $\$ 0$ for each year. As such, estimated taxable income to common shareholders is $\$ 224,072, \$ 257,807$ and $\$ 125,471$ (in thousands) for 2006, 2005 and 2004.

The approach I propose in this paper is to start with the Form 1099-DIV disclosures and back in to taxable income. Weighted basic common shares for 2006, 2005 and 2004 are 87,710,500, 84,048,936 and $82,133,627$, respectively. I first multiply each dividend component by weighted basic common shares for each year. Since a nontaxable return of capital is a distribution in excess of earnings and profits (E\&P) and E\&P is in most cases going to be close to taxable income, I can exclude the return of capital component in calculating taxable income. AMB reports taxable income to common shareholders including taxable capital gains, so to back into this measure of taxable income I take the ordinary income and capital gains (including unrecaptured section 1250 gains) components and sum them. This is 
reported as OI+CG in Table A2. As can be seen my method yields an estimate of taxable income to common shareholders of $\$ 78,062,345, \$ 184,067,170$ and $\$ 106,773,715$ for 2006,2005 and 2004, respectively.

Table A2 a Calculating taxable income.

\begin{tabular}{|c|c|c|c|}
\hline & \$per share & Shares & Total \\
\hline \multicolumn{4}{|l|}{2006} \\
\hline Ordinary Income & 0.53 & $87,710,500$ & $\$ 46,486,565$ \\
\hline Capital Gain & 0.36 & $87,710,500$ & $\$ 31,575,780$ \\
\hline Return of Capital & 0.49 & $87,710,500$ & $\$ 42,978,145$ \\
\hline $\mathrm{OI}+\mathrm{CG}$ & & & $\$ 78,062,345$ \\
\hline $90 \%$ of OI & & & $\$ 41,837,909$ \\
\hline \multicolumn{4}{|l|}{2005} \\
\hline Ordinary Income & 0.5 & $84,048,936$ & $\$ 42,024,468$ \\
\hline Capital Gain & 1.69 & $84,048,936$ & $\$ 142,042,702$ \\
\hline Return of Capital & 0 & $84,048,936$ & $\$ 0$ \\
\hline $\mathrm{OI}+\mathrm{CG}$ & & & $\$ 184,067,170$ \\
\hline $90 \%$ of OI & & & $\$ 37,822,021$ \\
\hline \multicolumn{4}{|l|}{2004} \\
\hline Ordinary Income & 0.78 & $82,133,627$ & $\$ 64,064,229$ \\
\hline Capital Gain & 0.52 & $82,133,627$ & $\$ 42,709,486$ \\
\hline Return of Capital & 0.39 & $82,133,627$ & $\$ 32,032,115$ \\
\hline $\mathrm{OI}+\mathrm{CG}$ & & & $\$ 106,773,715$ \\
\hline $90 \%$ of OI & & & $\$ 57,657,806$ \\
\hline \multicolumn{4}{|c|}{$\begin{array}{l}\text { This table reports estimates of taxable income for AMB Property Corporation for } 2006 \text {, } \\
2005 \text { and 2004. Ordinary Income, Capital Gains and Return of Capital components } \\
\text { are as reported in AMB's } 200610 \mathrm{~K} \text {. Shares are weighted basic shares as reported in } \\
\text { AMB's } 10 \mathrm{~K} \text {. OI + CG is the sum of the dollar total of ordinary income and capital gains } \\
\text { components. } 90 \% \text { of OI is } 90 \% \text { of the ordinary income component. }\end{array}$} \\
\hline
\end{tabular}

Table A3 reports the estimated taxable income under my method and Hardin and Hill's (2008) method and compares them to the taxable income reported by AMB. As can be seen, the deviations between Hardin and Hill's (2008) estimate and actual taxable income can be extremely large. For 2006, the Hardin and Hill (2008) method misestimates taxable income by nearly $\$ 150$ million. This confirms the arguments of Hanlon (2003) that trying to estimate taxable income from GAAP disclosures is likely to lead to large errors. What drives the large differences between Hardin and Hill's (2008) estimate and actual taxable income are the GAAP/Tax differences reported in AMB's full reconciliation above. For example, in 2006 the difference between the GAAP and Tax treatment of stock option compensation was approximately $\$-50$ million, for the gain on sale of real estate it was approximately $\$-109$ million and for depreciation it was approximately $\$ 22$ million. Because these GAAP/Tax differences are likely to be nonzero for every REIT in every year, Hardin and Hill's (2008) estimate of taxable income will be a good approximation to true taxable income only when the net result of these adjustments happens by chance to be close to zero. 
Table A3 a Errors in taxable income.

\begin{tabular}{|c|c|c|c|}
\hline Year & Reported & Hardin and Hill & 1099-DIV \\
\hline 2006 & $\$ 77,999,000$ & $\$ 224,072,000$ & $\$ 78,062,345$ \\
\hline 2005 & $\$ 184,674,000$ & $\$ 257,807,000$ & $\$ 184,067,170$ \\
\hline \multirow[t]{2}{*}{2004} & $\$ 107,058,000$ & $\$ 125,471,000$ & $\$ 106,773,715$ \\
\hline & & Deviation & Deviation \\
\hline 2006 & & $\$ 146,073,000$ & $\$ 63,345$ \\
\hline 2005 & & $\$ 73,133,000$ & $\$(606,830)$ \\
\hline 2004 & & $\$ 18,413,000$ & $\$(284,285)$ \\
\hline
\end{tabular}

The method I use in this paper to calculate taxable income leads to very small estimations errors. In each year the error is less than $\$ 1$ million in absolute value. Although this example is only for one firm, the fact that my method yields results that are quite accurate is not surprising, because it avoids the major pitfalls of calculating taxable income, which are the major differences between GAAP/tax accounting. By starting with tax disclosures instead of GAAP disclosures my method is less prone to error from both a theoretical and practical perspective.

\section{Estimating Discretionary and Nondiscretionary Dividends}

Having estimated taxable income, both nondiscretionary and discretionary dividends can be calculated. Although I have shown that the Hardin and Hill (2008) measure is likely to be very inaccurate in calculating taxable income, I will calculate discretionary and nondiscretionary dividends following their method, because it highlights several other flaws in their methodology. Hardin and Hill (2008) take $90 \%$ of their calculated taxable income and use this as their measure of nondiscretionary dividends. They then compare this to SNL item 14,126 Common Dividends Paid (from the Statement of Cash Flows). This method is flawed from three perspectives. First, because Hardin and Hill (2008) use Net Income as the starting point for calculating taxable income and make no adjustment for preferred equity, their measure of taxable income is actually measured at the total equity level not the common equity level. As such, comparing it to common dividends paid makes little since. It is in effect an applesto-oranges comparison.

Second, in calculating their nondiscretionary dividend, Hardin and Hill (2008) have ignored the fact that net capital gains are not required to be distributed under IRC section 857 in order for the REIT to maintain status. The effect of this is quite evident by examining AMB's dividend in 2005. In 2005, $\$ 1.69$ per share or approximately $77 \%$ of $A M B^{\prime}$ s dividend was in the form of a capital gains dividend. 
AMB could have chosen to retain these capital gains and paid tax on them, and this would have had no effect on their REIT status. As discussed in this paper, there are reasons to argue that capital gains should be paid out by the firm. However, Hardin and Hill (2008) are explicitly calculating the level of dividends required to maintain status. Including net capital gains in this calculation is clearly incorrect.

Finally, AMB does not report common dividends paid in the statement of cash flows, they report a combined figure for both common and preferred dividends paid. Using SNL this would result in a data error (if a line item is not reported SNL leaves it as a blank.) In this case, AMB would not appear in the sample even though they actually make more tax disclosures than is required under GAAP.

The approach I propose in this paper does not suffer from the same flaws as Hardin and Hill (2008). First, in calculating taxable income, my approach starts at the common equity level and compares to common dividends. Second, I propose two alternative definitions of nondiscretionary dividends. The first is the level of dividends required to maintain REIT status. This is $90 \%$ of the ordinary income component. The second definition is the sum of the ordinary income and capital gains components. This is the distribution level that eliminates the firm's federal income tax burden. Below this level the firm is transferring wealth from shareholders to the government. Finally, because I use the mandatory disclosures of Form 1099-DIV, I am always able to obtain common dividends and as such as less prone to missing observations.

Table A4 $\square$ Discretionary and nondiscretionary dividends.

\begin{tabular}{llll}
\hline \hline Year & Dividends & Nondiscretionary & Discretionary \\
\hline \multicolumn{2}{l}{ Panel A: Maintaining status } & & \\
\hline 2006 & 1.38 & 0.477 & 0.903 \\
2005 & 2.19 & 0.45 & 1.74 \\
2004 & 1.69 & 0.702 & 0.988 \\
\hline \multicolumn{2}{l}{ Panel B: Eliminating tax } & & \\
\hline 2006 & 1.38 & 0.89 & 0.39 \\
2005 & 2.19 & 2.19 & 0 \\
2004 & 1.69 & 1.3 & 0.39 \\
\hline
\end{tabular}

Table reports discretionary and nondiscretionary dividends for AMB Property Corporation for 2004-2006. Panel A reports nondiscretionary dividends at the level required to maintain REIT status. Panel B reports nondiscretionary dividends at the level required to eliminate the REIT's federal income tax burden. All values are in dollars per share.

Table A4 reports the discretionary and nondiscretionary dividends calculate for AMB using the method proposed in this paper. Panel A uses maintaining status as the benchmark, whereas Panel B 
uses eliminating tax as the benchmark. As can be seen in both panels, discretionary dividends are both large in magnitude and vary through time.

\section{Limitations of My Methodology}

Although my methodology provides very accurate results for AMB Property Corporation, the fact that it does so is because AMB distributes all of their taxable income and net capital gains in dividends. If a REIT were to not do this, then E\&P would not be a good proxy for taxable income and hence the ordinary income component would not be a good proxy for taxable income. Although this is an obvious concern, I do not believe it is a significant issue in the sample. The reason for this is that I would be able to observe this behavior in the income taxes paid by the REIT. If the REIT retains its capital gains or distributes less than $100 \%$ of its taxable income, then these would be taxed at the corporate level and would be disclosed in the firm's financial statements. Notice that if the firm has a nontaxable return of capital distribution in a given year, then I know this is not a problem.

To examine this issue I examine the set of firms in the sample most likely to suffer from this problem. There are 13 REITs in the sample that never paid a nontaxable return of capital distribution. If they were retaining taxable income or capital gains then I would observe positive taxes paid. For the vast majority of years, these firms had zero income tax paid. When income tax paid was not zero the firm either had an operating loss or an examination of the 10-K identified that the income tax paid was the result of a Taxable REIT Subsidiary. Although not definitive proof that REITs do not retain taxable income and capital gains, it suggests that if it does occur it is likely to be a very rare event.

Although the methodology described in this paper appears to accurately estimate taxable income, this in no way diminishes the usefulness of REITs making discretionary taxable income disclosures in their financial statements. If all REITs followed NAREIT's 2001 Best Reporting Practices white paper in making these disclosures, then both academics and investors would have readily available and accurate measures of taxable income. 